\title{
Insulin-Like Growth Factor and Potassium Depolarization Maintain Neuronal Survival by Distinct Pathways: Possible Involvement of PI 3-Kinase in IGF-1 Signaling
}

\author{
Santosh R. D'Mello, ${ }^{1}$ Kristin Borodezt, ${ }^{1}$ and Stephen P. Soltoff ${ }^{2}$ \\ ${ }^{1}$ Department of Physiology and Neurobiology, University of Connecticut, Storrs, Connecticut 06269 and ${ }^{2}$ Division of \\ Signal Transduction, Beth Israel Hospital, Harvard Institutes of Medicine, Boston, Massachusetts 02215
}

\begin{abstract}
Cultured cerebellar granule neurons die by apoptosis when switched from a medium containing an elevated level of potassium $\left(\mathrm{K}^{+}\right)$to one with lower $\mathrm{K}^{+}(5 \mathrm{~mm})$. Death resulting from the lowering of $\mathrm{K}^{+}$can be prevented by insulin-like growth factor (IGF-1). To understand how IGF-1 inhibits apoptosis and maintains neuronal survival, we examined the role of phosphoinositide 3-kinase (PI 3-kinase). Activation of PI 3-kinase has been shown previously to be required for NGF-mediated survival in the PC12 pheochromocytoma cell line. We find that in primary neurons, IGF-1 treatment leads to a robust activation of $\mathrm{PI}$ 3-kinase, as judged by lipid kinase assays and Western blot analysis. Activation of PI 3-kinase is likely to occur via tyrosine phosphorylation of the insulin receptor substrate protein. Treatment with two chemically distinct inhibitors of PI 3-kinase, wortmannin and LY294002, reduces PI 3-kinase activation by IGF-1 and inhibits its survival-promoting activity, suggesting
\end{abstract}

that PI 3-kinase is necessary for IGF-1-mediated survival. Death resulting from $\mathrm{PI}$ 3-kinase blockade is accompanied by DNA fragmentation, a hallmark of apoptosis. Furthermore, neurons subjected to $\mathrm{PI}$ 3-kinase blockade can be rescued by transcriptional and translation inhibitors, suggesting that IGF1-mediated activation of PI 3-kinase leads to a suppression of "killer gene" expression. In sharp contrast to IGF-1, elevated $\mathrm{K}^{+}$does not activate PI 3-kinase and can maintain neuronal survival in the presence of PI 3-kinase inhibitors. Therefore, survival of granule neurons can be maintained by PI 3-kinase dependent (IGF-1-activated) and independent (elevated $\mathrm{K}^{+}$activated) pathways.

Key words: cerebellar granule neurons; phosphoinositide 3-kinase; apoptosis; insulin-like growth factor-1; elevated potassium; neuronal survival
During development of the vertebrate nervous system, approximately half of the neurons that are generated die by a process called "programmed cell death." This naturally occurring process is mediated by apoptosis, a specific form of programmed cell death that has characteristic morphological and biochemical features (for review, see Oppenheim, 1991; Johnson and Deckworth, 1993). A key determinant of which neurons survive during this developmental period is the availability of neurotrophic factors, a class of growth factors generally secreted by targets of neuronal innervation (Oppenheim, 1991; Johnson and Deckworth, 1993). Several such factors have been identified in mammalian systems in recent years, and these include the neurotrophins: nerve growth factor (NGF), brain-derived neurotrophic factor (BDNF), neurotrophin-3, neurotrophin$4 / 5$, insulin-like growth factor-1 (IGF-1), and the fibroblast growth factors (FGFs).

Although neurotrophic factors are most often associated with their ability to support survival, they are also involved in a variety of other neuronal processes such as differentiation, plasticity, maintenance of specific neuronal functions, and the regulation of neuronal cell fate and precursor proliferation (for review, see Schlessinger and Ullrich, 1992). The mechanisms by which growth

\footnotetext{
Received Sept. 27, 1996; revised Nov. 27, 1996; accepted Dec. 9, 1996.

This work was supported by grants from the Whitehall Foundation, the AT Children's Project, the University of Connecticut Research Foundation, and the National Science Foundation (Grant IBN-9511013) to S.R.D.

Correspondence should be addressed to Dr. Santosh R. D'Mello, Department of Physiology and Neurobiology, U156, University of Connecticut, Storrs, CT 06269. Copyright (C) 1997 Society for Neuroscience $0270-6474 / 97 / 171548-13 \$ 05.00 / 0$
}

factors generate such diverse actions remain unclear and the subject of intense investigation. The receptors for a number of these factors have intrinsic tyrosine kinase activity. Furthermore, recent studies have shown that the intracellular kinase regions of these receptors possess distinct motifs capable of specifically interacting with a repertoire of effector proteins containing src homology 2 (SH2) and src homology 3 (SH3) domains (for review, see Chao, 1992; Schlessinger and Ullrich, 1992; Schlessinger et al., 1992; Kapeller and Cantley, 1994). Differential interaction of the receptor tyrosine kinase with $\mathrm{SH} 2$ proteins therefore may provide one mechanism by which some diversity in growth factor action may be generated (Valius and Kazlauskas, 1993; Obermeir et al., 1994). Cell-specific expression of receptor tyrosine kinases and various $\mathrm{SH} 2$-containing proteins may also explain why a given growth factor is capable of inducing distinct or even opposite effects in different cell types (Cordon-Cardo et al., 1991). Other domains, such as PTB and PTZ domains, may also contribute to interaction of signaling proteins (Harrison, 1996). The kinetics and magnitude of effector protein activation may also contribute to the action of growth factors (Qui and Green, 1992; Traverse et al., 1992; Marshall, 1995).

Although receptor properties, cellular context, and kinetics of activation may explain how growth factors elicit distinct biological actions, a question of fundamental importance is whether similar signaling components are used by different growth factors toward a common biological effect. One of the most striking properties of neurotrophic factors is their ability to maintain neuronal survival by inhibition of apoptosis. Most investigations of the signaling pathways involved in the prevention of apoptosis by neurotrophic 

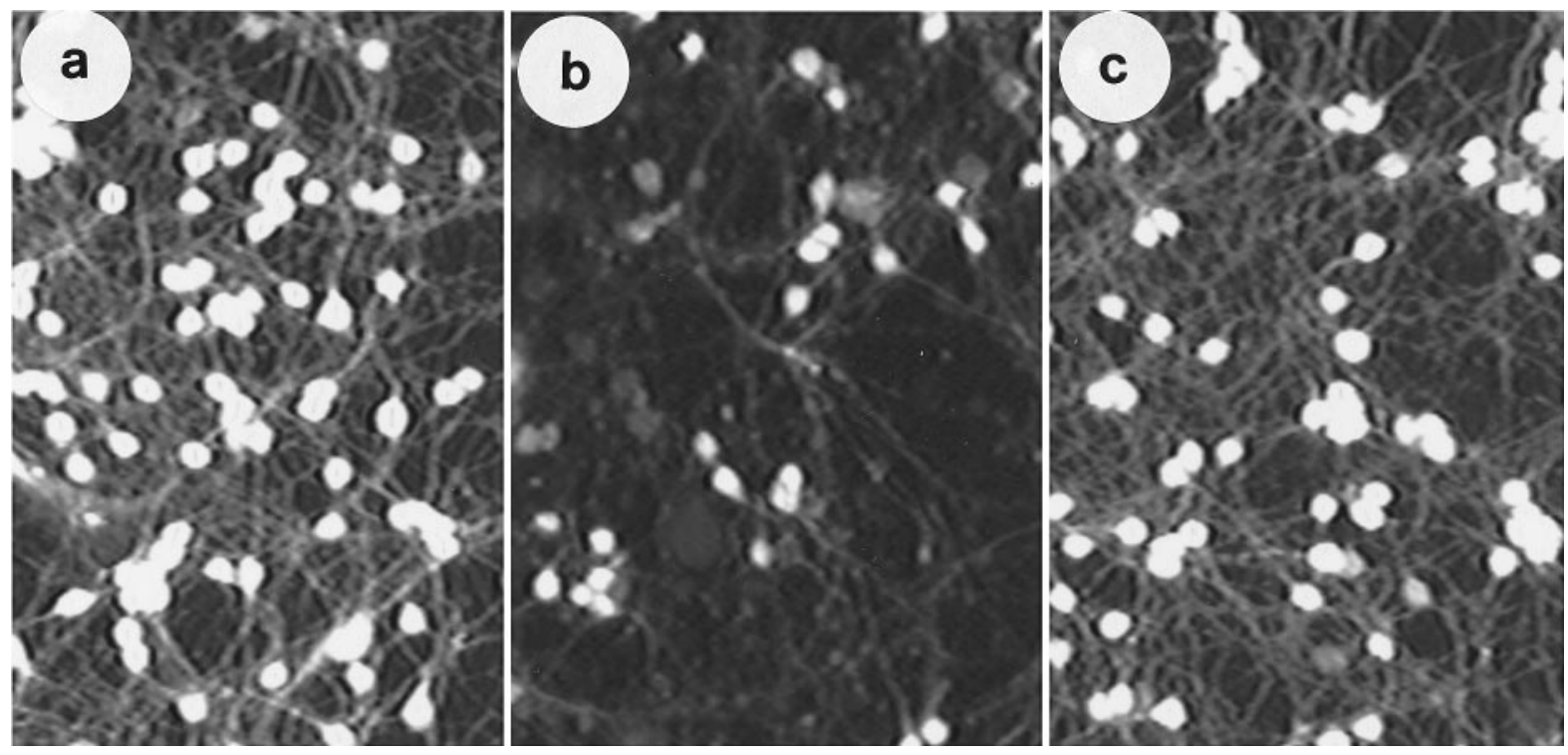

Figure 1. IGF-1 can substitute for elevated $\mathrm{K}^{+}$in the maintenance of neuronal survival. Granule neurons were cultured in BME supplemented with high $\mathrm{K}^{+}(25 \mathrm{~mm} \mathrm{KCl})$ and $10 \% \mathrm{FCS}$. After $7 \mathrm{~d}$, the cultures were switched to serum-free BME (normally containing $5 \mathrm{~mm} \mathrm{KCl)} \mathrm{supplemented} \mathrm{with}(a) 25 \mathrm{~mm}$ $\mathrm{KCl},(b)$ no additives, and (c) IGF-1 $(25 \mathrm{ng} / \mathrm{ml})$. The figure shows fluorescent imaging of cultures by FDA staining at $24 \mathrm{hr}$ after treatment. Note an increased number of fluorescent (viable) cells in elevated $\mathrm{K}^{+}$and IGF-1 treated cultures $(a, c)$ compared with culture switched to low $\mathrm{K}^{+}(b)$. For viability assays, an $0.85 \mathrm{~mm}^{2}$ field is randomly chosen from the culture dish and acquired using the NIH Image program. Stained cells in each field are then computed. In subsequent figures, phase-contrast micrographs that better display morphological appearance of the cultures have been used.

factors have been performed using the rat pheochromocytoma PC12 cell line (Greene and Tischler, 1976). When switched to serum-free medium, these cells undergo apoptosis (Batistatou and Greene, 1991; Mesner et al., 1992), which can be prevented by NGF or FGF (Rukenstein et al., 1991). Using the PC12 cell system, Yao and Cooper (1995) discovered recently that a critical component of the survival-promoting action of NGF is the SH2containing enzyme phosphoinositide 3-kinase (PI 3-kinase).

PI 3-kinase is a heterodimer of a $85 \mathrm{kDa}$ regulatory subunit and a $110 \mathrm{kDa}$ catalytic subunit (Carpenter et al., 1990; Morgan et al., 1990; Escobedo et al., 1991; Hiles et al., 1992). The enzyme phosphorylates PI, PI-4P, and PI-4,5-P2 on the D3 position of the inositol ring, leading to the formation of the lipids PI-3P; PI-3,4P2; and PI-3,4,5-P3; respectively (for review, see Stephens et al., 1993; Kapeller and Cantley, 1994). Downstream target molecules of PI 3-kinase activation have not been definitively identified, although activation of certain serine/threonine kinases has been suggested (Toker et al., 1994; Burgering and Coffer, 1995; Franke et al., 1995). In addition to inhibiting apoptosis, activation of PI 3-kinase has been implicated in mitogenic signaling, metabolic processes (such as glucose uptake and superoxide production), membrane ruffling, and chemotaxis (for review, see Cantley et al., 1991 and Kapeller and Cantley, 1994).

Although PI 3-kinase is required for prevention of apoptosis in PC12 cells, the generality of this finding remains to be explored. Of particular interest is the question of whether PI 3-kinase is critical for the survival of normal neurons. Also unclear is whether neurotrophic factors other than NGF also use PI 3-kinase to support survival. To address these issues, we have used granule neurons cultured from postnatal rat cerebella. These cells constitute the most abundant neuronal population in the mammalian brain. When cultured from early postnatal rats, granule cells differentiate in vitro, acquiring several morphological, biochemical, and electrophysiological characteristics of mature neurons (Levi et al., 1984; Gallo et al.,
1987; Hockberger et al., 1987; Cull-Candy et al., 1988). An elevated level of $\mathrm{K}^{+}(25 \mathrm{~mm})$ is necessary for the survival and differentiation of these neurons in culture (Lasher and Zaigon, 1972; Gallo et al., 1987). We have demonstrated previously that when switched from a culture medium containing high $\mathrm{K}^{+}(25$ $\mathrm{mm}$ ) to a lower, but physiological $\mathrm{K}^{+}$medium (5 mM), fully differentiated granule neurons undergo apoptosis (D'Mello et al., 1993). Death by lowering of $\mathrm{K}^{+}$can be prevented by IGF-1 but not by several other growth factors including FGF, NGF, BDNF, and neurotrophin-3 (D'Mello et al., 1993). Several pieces of evidence suggest that IGF-1 may be physiologically important for the development of granule neurons (Bondy et al., 1991; Gao et al., 1991; Calissano et al., 1993; Ye et al., 1996). Although mice-lacking functional IGF-1 have no dramatic deficit in granule cell number (Beck et al., 1995) presumably because of compensatory effects from related factors, other studies have shown that overexpression of IGF-1 increases proliferation and survival of granule cells (Ye et al., 1996). Beside its beneficial effect on granule cells, IGF-1 promotes the in vitro survival and neurite outgrowth of various sensory, sympathetic, cortical, and motor neurons (Aizenman and de Vellis, 1987; Caroni and Grandes, 1990, Svrzic and Schubert, 1990; Neff et al., 1993) (for review, see BozyczkoCoyne et al., 1993).

We report that IGF-1 activates PI 3-kinase in cerebellar granule neurons and that the pharmacological inhibitors of PI 3-kinase prevent the survival-promoting action of IGF-1. In contrast, the elevation of extracellular $\mathrm{K}^{+}$maintains survival of the same neurons by a PI 3-kinase-independent mechanism. Thus, cell survival and the block of apoptosis may occur by both PI 3-kinasedependent and -independent pathways in granule neurons.

\section{MATERIALS AND METHODS}

Chemicals. All chemicals were reagent grade or better. $\left[{ }^{32} \mathrm{P}\right] \mathrm{ATP}$ (specific activity, $3000 \mathrm{Ci} / \mathrm{mmol}$ ) was obtained from DuPont NEN (Boston, MA). 
Figure 2. IGF-1 activates PI 3-kinase in granule neurons. $a$, Measurement of lipid kinase activity in anti-P-Tyr immunoprecipitates from cortical neurons. Cells were maintained overnight in serum-free medium containing $25 \mathrm{~mm}$ $\mathrm{K}^{+}$, and then exposed (or not) to IGF-1 $(25 \mathrm{ng} / \mathrm{ml}$ ) for $1 \mathrm{~min}$. PI 3-kinase was immunoprecipitated from the cleared lysates using anti-P-Tyr antibody (6.6 $\mu \mathrm{g} / \mathrm{ml}$ ), and PI 3-kinase activity was measured using PI-4,5-P2 as a substrate. PI-3,4,5-P3 (PIP3), the main product of the lipid kinase assay, was identified using thin-layer chromatography. $b$, Immunoprecipitation of $\mathrm{p} 85$, the regulatory subunit of PI 3-kinase, from lysates of IGF-1-treated cells. The immunoprecipitated proteins used in the lipid kinase assay $(a)$ were subjected to SDS-PAGE, transferred to nitrocellulose filters, and probed overnight with anti-p85 antibody (1:8000 dilution). The arrow on the right indicates the location of $\mathrm{p} 85$. The addition of IGF-1 produced a large increase in the amount of p85 that was immunoprecipitated using anti-P-Tyr antibody. $c$, Time course of PI 3-kinase activation by IGF-1. Granule neurons were exposed to IGF-1 $(25 \mathrm{ng} / \mathrm{ml})$ for various times between 1 and $60 \mathrm{~min}$. Proteins were immunoprecipitated using anti-PTyr antibody, and PI 3-kinase activity was measured in the immunoprecipitates using PI-3,4-P2 as a substrate. The activities were normalized to the PI 3-kinase activity found at $1 \mathrm{~min}$ after IGF-1 treatment of cells cultured in serum-free medium containing $25 \mathrm{~mm}$ $\mathrm{K}^{+}$. This time point always had the greatest activity. The values for the basal time (time 0), $1 \mathrm{~min}$, and $5 \mathrm{~min}$ time points are the mean \pm SEM of three separate experiments. The values at 15 and $60 \mathrm{~min}$ were obtained from 1 and 2 of these same experiments, respectively.

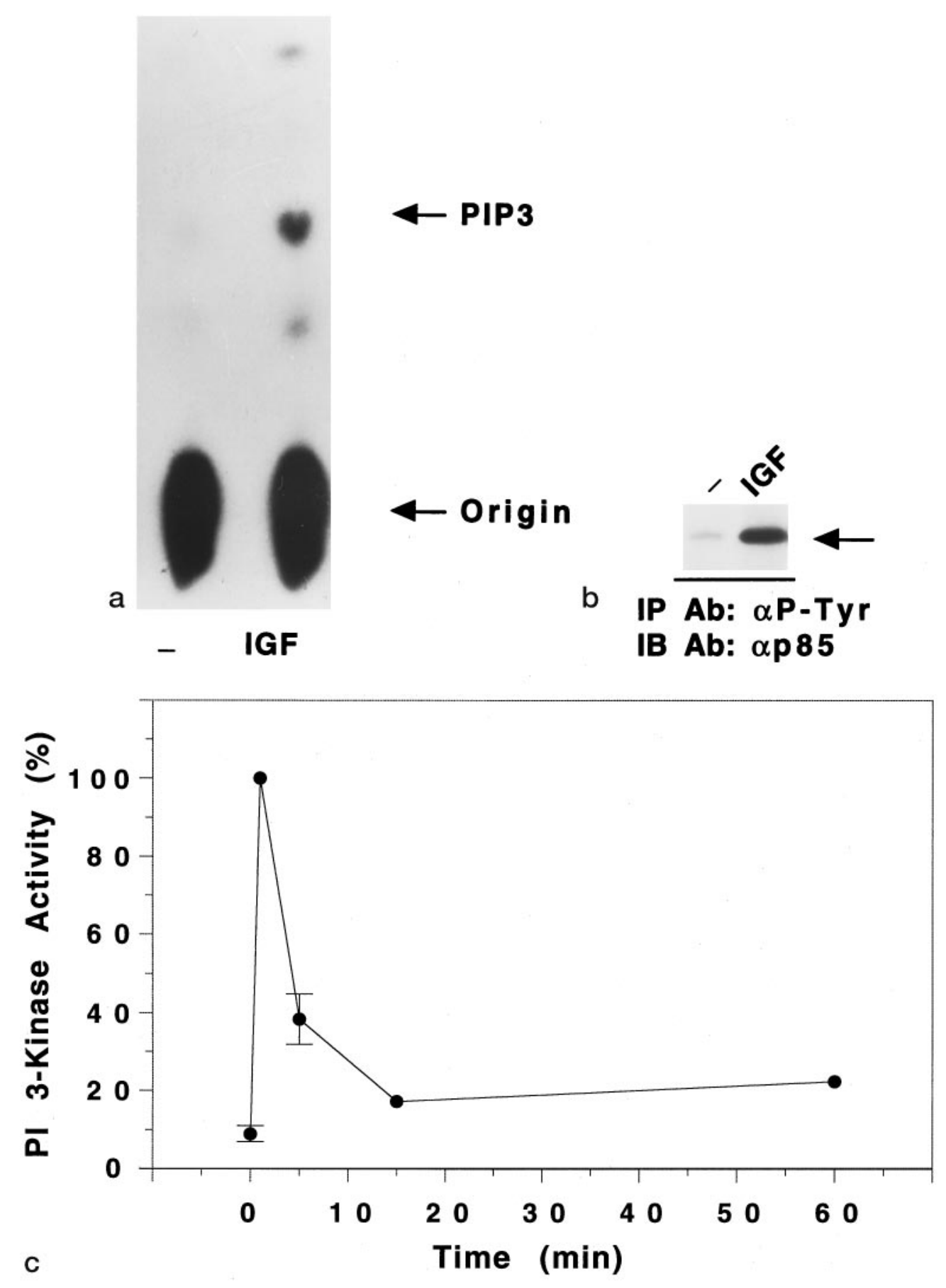

PI-4,5-P2 was obtained from Sigma (St. Louis, MO). Recombinant human IGF-1 and bFGF were purchased from Boehringer Mannheim Indianapolis, IN) and LY294002 from Biomol (Plymouth Meeting, PA). All other agents were obtained from Sigma. Recombinant mouse BDNF was a gift from Fidia Pharmaceuticals, Abano Terme, Italy.

Antibodies. Antibody to the p85 subunit of PI 3-kinase was raised in rabbits by Dr. Brian Schauffhausen (Tufts University, Boston, MA) and is commercially available from Upstate Biotechnology (Lake Placid, NY) (catalog no. 06-195), as is anti-phosphotyrosine antibody, clone 4G10 (05-321). An antibody made to insulin receptor substrate (IRS)-1 was generously donated by Dr. Ken Siddle (University of Cambridge, Cambridge, UK).

Primary neuronal cultures. Cultures enriched in granule neurons were obtained from dissociated cerebella of 8-d-old Wistar rats (Charles River, Wilmington, MA), as described by Thangnipon et al. (1983). After preparation, cells were plated in basal Eagle's medium (BME, Life
Technologies, Gaithersburg, MD) supplemented with 10\% FCS, $25 \mathrm{~mm}$ $\mathrm{KCl}, 2 \mathrm{~mm}$ glutamine (Life Technologies), and $100 \mu \mathrm{g} / \mathrm{ml}$ gentamycin (Life Technologies) on dishes (Nunc, Naperville, IL) coated with polyL-lysine. Cells were plated at a density of $3 \times 10^{5}$ per $\mathrm{cm}^{2}\left(2.5 \times 10^{6}\right.$ cells $/ 35 \mathrm{~mm}$ dish or $25 \times 10^{6} / 100 \mathrm{~mm}$ dish). Cytosine arabinofuranoside $(10 \mu \mathrm{M})$ was added to the culture medium 18-22 hr after plating to prevent replication of non-neuronal cells. Immunocytochemical analysis of these primary cultures have shown that they contain $>95 \%$ granule neurons (Thangnipon et al., 1983). Also, these cultures have been studied extensively and shown to posses the biochemical and electrophysiological characteristics of their counterparts in vivo (Levi et al., 1984; Gallo et al., 1987; Hockberger et al., 1987; Cull-Candy et al., 1988).

Treatment of cultures. Replacement of culture medium with serum-free medium was performed 7-8 d after plating as follows. Cells were washed once and maintained in serum-free BME culture medium supplemented with glutamine, gentamycin, and cytosine arabinofuranoside at the con- 

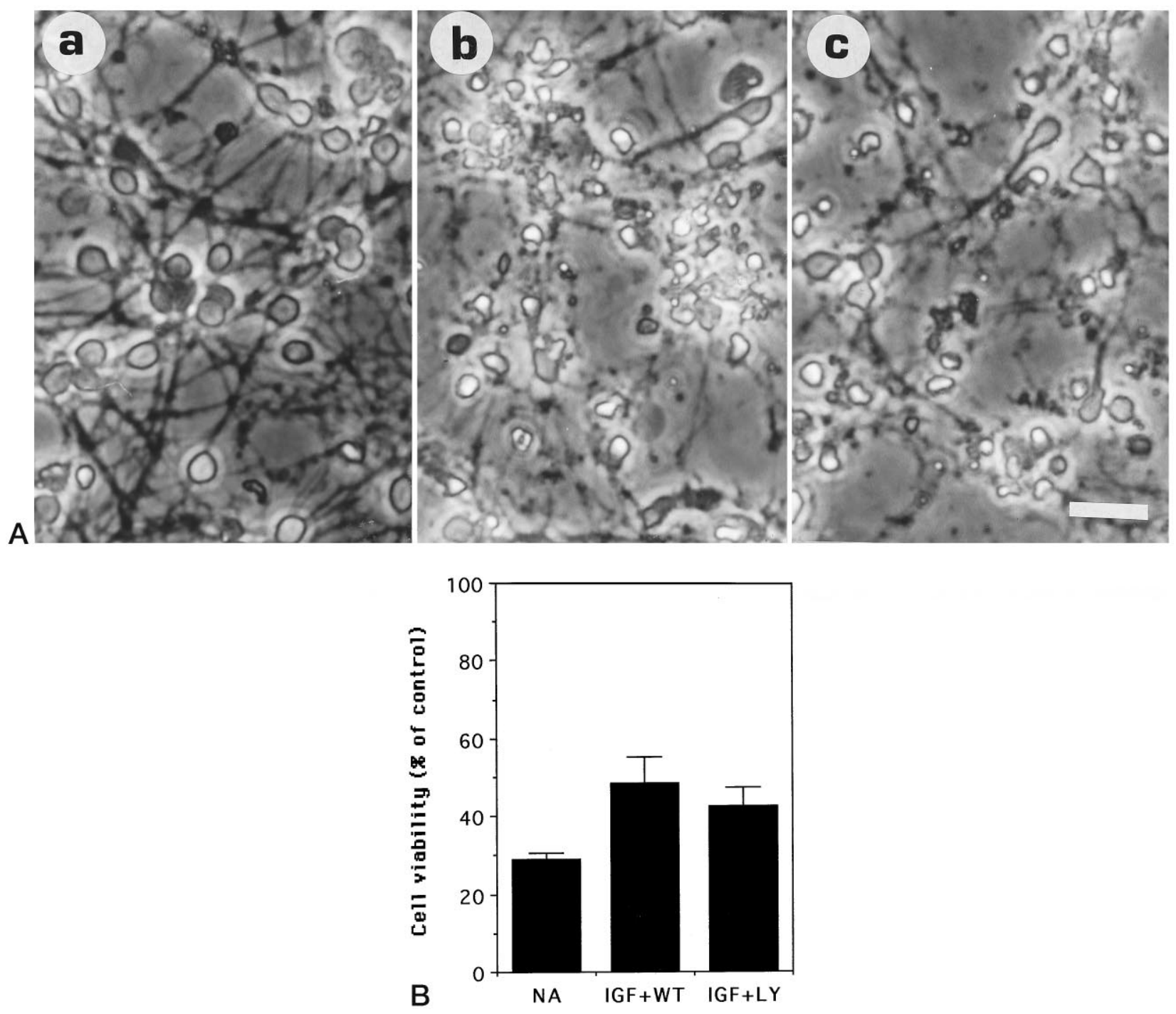

Figure 3. Wortmannin and LY249002 inhibit the survival-promoting activity of IGF-1. Granule neurons maintained in high $\mathrm{K}^{+}$and FCS (see Materials and Methods) were switched to serum-free medium containing (a) $25 \mathrm{ng} / \mathrm{ml} \mathrm{IGF-1,} \mathrm{(b)} 25 \mathrm{ng} / \mathrm{ml} \mathrm{IGF-1}+50 \mathrm{~nm}$ wortmannin, and (c) $25 \mathrm{ng} / \mathrm{ml} \mathrm{IGF}+$ $10 \mu \mathrm{M}$ LY249002. $A$, Morphological appearance at $24 \mathrm{hr}$. Scale bar, $20 \mu \mathrm{M}$. B, Neuronal viability at $24 \mathrm{hr}$ after treatment, measured by FDA staining, normalizing the data to the control (cells maintained in IGF-1) conditions. No additives, IGF-1, wortmannin, and LY249002 are designated as $N A$, IGF, $W T$, and $L Y$, respectively. Error bars indicate mean $\pm \mathrm{SD}$ of data shown from three experiments performed in duplicate culture dishes. Two fields were examined from each dish.

centrations indicated above. The $\mathrm{KCl}$ concentration in serum-free media was $5 \mathrm{~mm}$, unless specified otherwise. Factors and agents were added directly to the serum-free medium. Unless indicated otherwise, treatment with wortmannin or LY294002 included a pretreatment in which the drug was added to the cultures $15 \mathrm{~min}$ before exposure to stimuli.

Neuronal survival. Neuronal survival was quantified in cultures grown in $35 \mathrm{~mm}$ dishes by staining with $10 \mu \mathrm{g} / \mathrm{ml}$ fluorescein diacetate (FDA, Sigma), as described (Jones and Senft, 1985). Viable cells are indicated by bright green on examination with a fluorescence microscope. Two fields from each dish were chosen randomly, and an area of $0.85 \mathrm{~mm}^{2}$ was acquired using the NIH Image program. The number of surviving cells in the field were then computed. Typically, in healthy cultures (maintained in high $\mathrm{K}^{+}$or IGF-1), the number of viable cells was $200-250$ /acquired field.

DNA fragmentation analysis. Fragmentation of DNA was analyzed as described previously (D'Mello et al., 1993). Equal numbers of cells $(2.5 \times$ $\left.10^{6}\right)$ were plated and used for each set of treatments. After cell lysis and elimination of nuclei, soluble DNA was isolated. After treatment with RNAse A $(50 \mathrm{ng} / \mathrm{ml})$ at $37^{\circ} \mathrm{C}$ for $30 \mathrm{~min}$, the DNA was subjected to electrophoresis on a $1.5 \%$ agarose gel and visualized by ethidium bromide staining. Because the same number of cells were plated for each treatment, the amount of soluble DNA that is recovered reflects the extent of genomic DNA damage.

Measurement of PI 3-kinase activity. The cells were exposed to growth factors for the indicated times at $37^{\circ} \mathrm{C}$. Lysis of cells, immunoprecipitations, lipid kinase assays, and lipid extractions were performed as described previously (Soltoff et al., 1994). PI 3-kinase was immunoprecipitated using either anti-P-Tyr or anti-p85 antibodies, as specified. In experiments in which the in vitro wortmannin sensitivity of PI 3-kinase was analyzed, wortmannin was exposed to the immunoprecipitated PI 3-kinase for $15 \mathrm{~min}$ before addition of lipids and the kinase reaction mixture. Exogenous PI-4,5-P2 was used as substrate to measure PI 3-kinase activity. The lipid products were separating using thin-layer chromatography and a solvent system composed of $N$-propanol: acetic acid (2 M) (65:35, vol:vol). The production of PI-3,4,5-P3 was quantified using a Bio-Rad GS-363 Molecular Imager System.

Identification of proteins by Western blot assays. The electrophoresis of immunoprecipitated proteins and the Western blotting of proteins transferred from $7 \%$ polyacrylamide gels to nitrocellulose filters were performed as described previously (Soltoff et al., 1994). Proteins were visualized using a chemiluminescence system (Renaissance, Dupont NEN).

Data. Unless indicated otherwise, data are given as means + SEM, with 


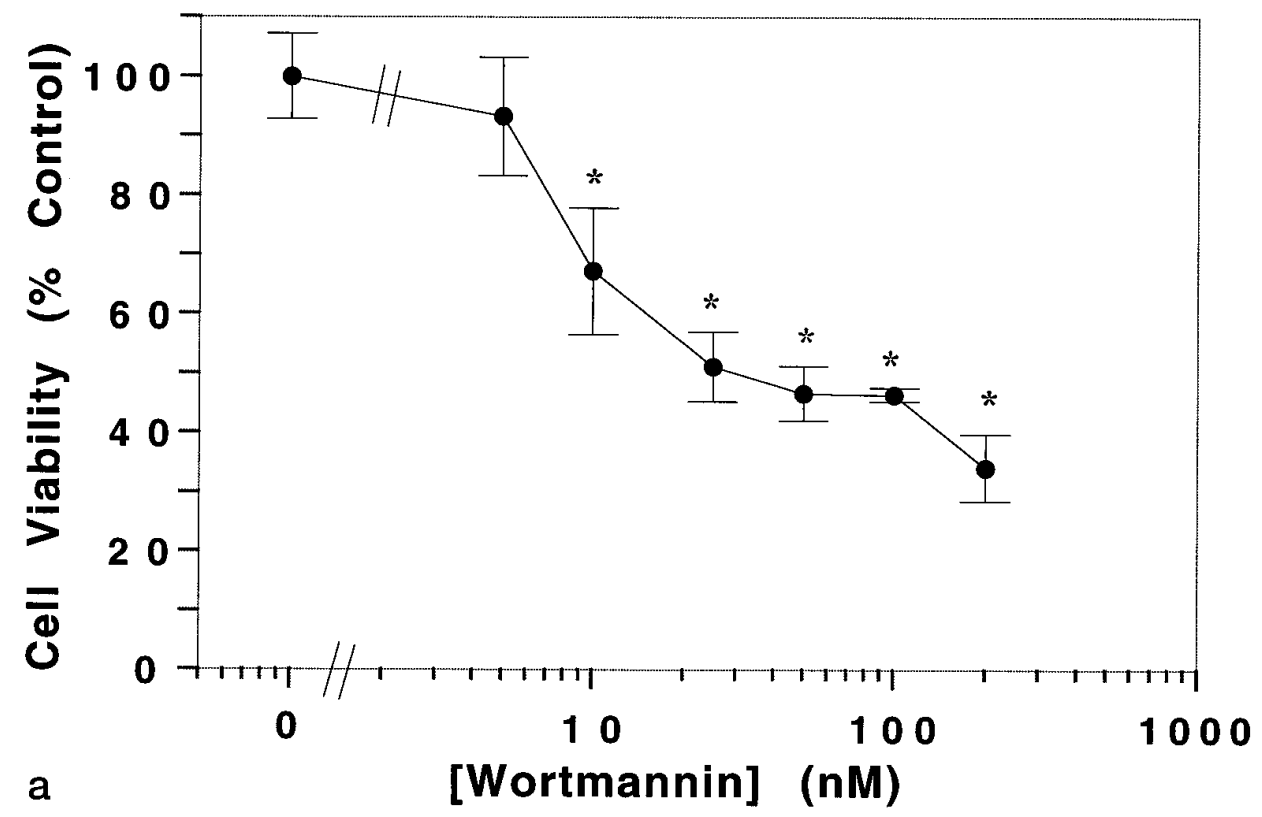

Figure 4. Dose response of wortmannin and LY249002 on granule neurons maintained in IGF-1. Cultures (7-dold) were switched to medium containing IGF-1 $(25 \mathrm{ng} / \mathrm{ml})$ and $(a)$ various concentrations of wortmannin and $(b)$ various concentrations of LY249002. The figure shows neuronal viability at $24 \mathrm{hr}$ after treatment. Error bars indicate mean $\pm \mathrm{SD}$ of data shown from three experiments performed in duplicate culture dishes. Two fields were examined from each dish. Asterisks indicate significant difference from control (no drug) treated cells $(p<0.05)$.

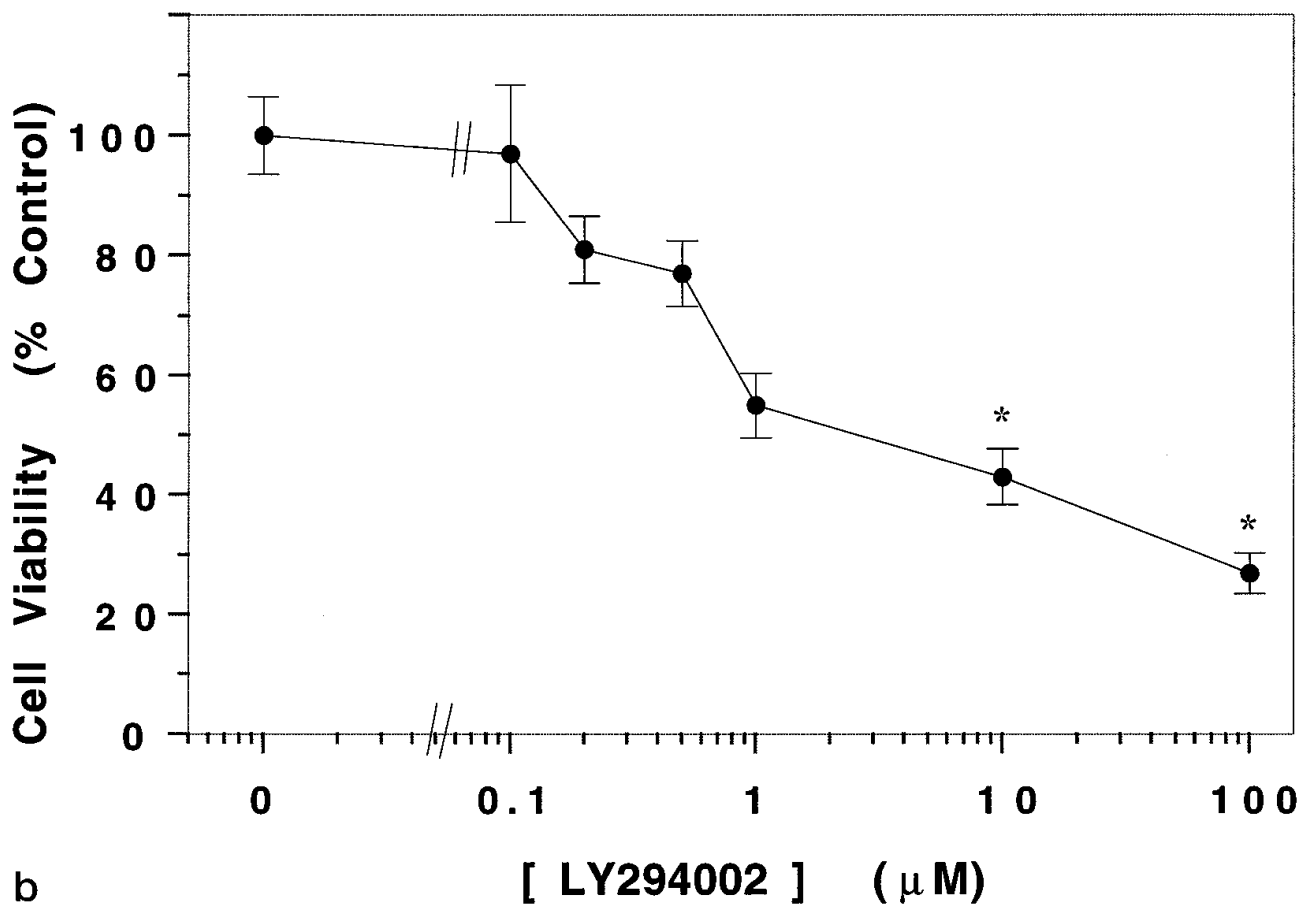

the number of determinations $(n)$ representing separate experiments performed using single or duplicate samples.

For statistical significance, data were evaluated at a 0.05 level of significance with the Kruskal-Wallis ANOVA. Differences between individual groups were evaluated by the Newman-Keuls test.

\section{RESULTS}

A key issue in attempting to understand signal transduction pathways is whether similar intracellular signaling components are used by distinct growth factors toward a common biological effect. PI 3-kinase has been shown previously to be necessary for NGFmediated survival of pheochromocytoma PC12 cells (Yao and Cooper, 1995). To examine whether this enzyme was also involved in promoting survival of normal neurons, we used cultures of rat cerebellar granule neurons.

\section{IGF-1 activates PI 3-kinase in granule neurons}

Granule neuron cultures were cultured and maintained in medium supplemented with $25 \mathrm{mM} \mathrm{KCl}$ for $7-8 \mathrm{~d}$, as described previously (D'Mello et al., 1993). The fully differentiated cultures were shifted to serum-free medium containing IGF-1. As we have reported previously (D'Mello et al., 1993) and as shown in Figure 1, IGF-1 (25 ng/ml) can efficiently substitute for high $\mathrm{K}^{+}$in the maintenance of neuronal survival. In contrast, a majority of neurons in sister cultures lacking IGF-1 (low- $\mathrm{K}^{+}$medium, $5 \mathrm{~mm} \mathrm{KCl}$ ) die within 24 hr (Fig. 1) (D’Mello et al., 1993).

As a first step toward testing the hypothesis that maintenance of survival by IGF-1 involved PI 3-kinase, we examined whether PI 3-kinase was activated by IGF-1. Granule neuron cultures 

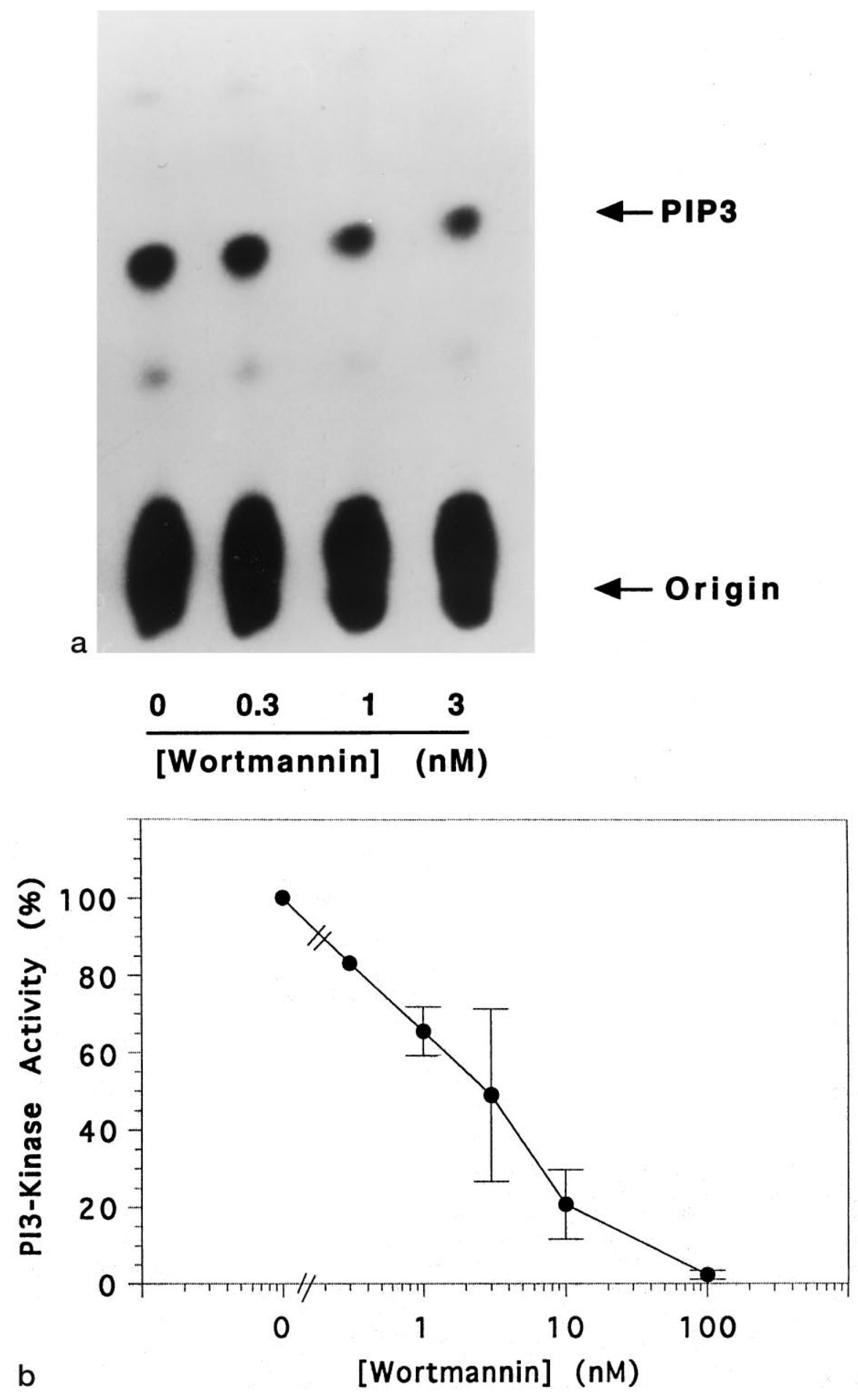

Figure 5. Wortmannin inhibits PI 3-kinase activity. $a$, PI 3-kinase activity was measured in lipid kinase assays using anti-p85 immunoprecipitates from lysates of granule cells maintained in high $\mathrm{K}^{+}$. Immunoprecipitates were exposed (or not) to different concentrations of wortmannin, as indicated. PI$3,4,5-\mathrm{P} 3$, the main product of the lipid kinase assay, was identified using thin-layer chromatography. $b$, The concentration dependence of the inhibition of PI 3-kinase activity by wortmannin. In each lipid kinase assay experiment, the data were normalized to the activity measured in the absence of wortman$\operatorname{nin}(0)$. Error bars indicate the mean values of three or four separate experiments, except for 0.3 nм $(n=1)$. were switched to medium containing IGF-1 (25 ng/ml). As shown in Figure $2 A$, treatment with $\mathrm{IGF}-1$ resulted in a robust activation of PI 3-kinase within $1 \mathrm{~min}$, as judged by the increased synthesis of PI-3,4,5-P3 by PI 3-kinase immunoprecipitated using anti-P-Tyr antibody. In these experiments, IGF-1 (1 $\mathrm{min})$ increased the PI 3-kinase activity to $12.8 \pm 2.0(10) \times$ the basal activity. Consistent with this, there was a large increase in the association of PI 3-kinase (p85 subunit) with anti-P-Tyr antibody (Fig. 2B). The increase in PI 3-kinase activity was maximal at $1 \mathrm{~min}$. Within $5 \mathrm{~min}$, the degree of activation was reduced, but it was sustained above basal levels for at least $1 \mathrm{hr}$ (Fig. 2C).

In other experimental systems such as adipocytes and muscle, activation of PI 3-kinase by insulin and IGF-1 occurs via insulin receptor substrate (IRS) proteins (Sun et al., 1991, 1992). We examined whether IRS proteins were similarly involved in IGF-1 signaling in neurons. Consistent with findings from other cell systems, IGF-1 stimulated a large increase in PI 3-kinase activity in granule neurons that was immunoprecipitated using an anti-IRS-1 antibody. Using this antibody, the PI 3-kinase 


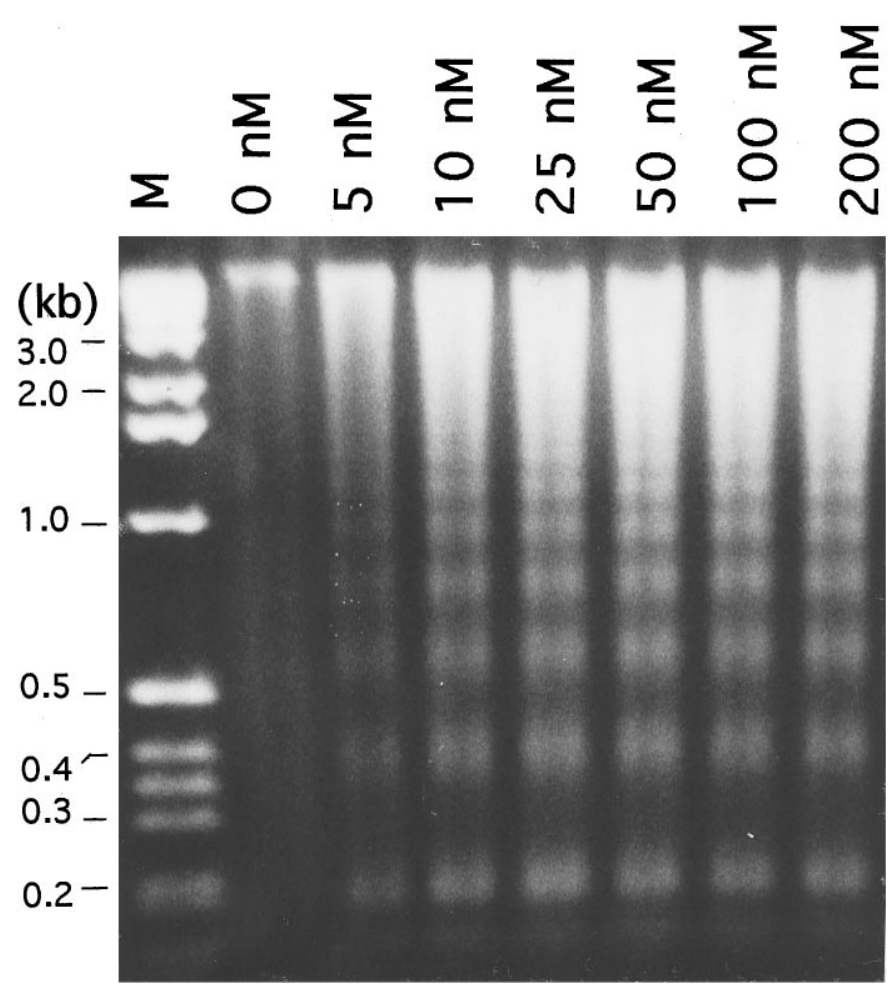

Figure 6. Wortmannin-mediated death of neurons maintained in IGF-1 is accompanied by DNA fragmentation, a marker of apoptosis. DNA fragmentation analysis of cultures maintained in serum-free medium supplemented with IGF-1 $(25 \mathrm{ng} / \mathrm{ml})$ and treated with various concentrations of wortmannin. The wortmannin concentration (in nanomolars) is indicated at the top. Soluble DNA was isolated $18 \mathrm{hr}$ after the switch, as described in Materials and Methods, treated with RNase A, and subjected to electrophoresis. Lane $M$ contains a molecular weight marker, and numbers on the left represent lengths in kilobases $(\mathrm{kb})$. The figure shows DNA visualized by ethidium bromide staining. Because the same number of cells was used for all concentrations, the amount of soluble DNA seen in each lane reflects the extent of DNA fragmentation. The small amount of fragmentation that is detectable in cultures treated with IGF-1 alone is attributable to the small amount of cell death observed when granule neurons are switched from high $\mathrm{K}^{+}$to IGF-1-containing medium (D’Mello et al., 1993).

activity immunoprecipitated from cells treated with IGF-1 for 1 min was $24.5 \pm 12.5$ (3) times the activity found in immunoprecipitations from untreated cells. Similar amounts of PI 3-kinase activity were immunoprecipitated from lysates of IGF1-treated cells (1 min) using anti-P-Tyr and anti-IRS-1 antibodies; in experiments conducted in parallel, the activity immunoprecipitated using anti-IRS- 1 antibody was $1.5 \pm 0.4$ (3) times that immunoprecipitated using anti-P-Tyr antibody. In Western blot analysis, we observed that IGF-1 promoted an increase in the tyrosine phosphorylation of an $\sim 170 \mathrm{kDa}$ protein that was immunoprecipitated using an anti-IRS- 1 antibody (data not shown). In addition, IGF-1 promoted an increase in the tyrosine phosphorylation of an $\sim 95 \mathrm{kDa}$ protein, the mass of the $\beta$ subunit of the IGF-1 receptor (data not shown). These results suggest that autophosphorylation of the IGF-1 receptor results in binding and subsequent tyrosine phosphorylation of IRS-1, which in turn binds and activates PI 3-kinase.

\section{PI 3-kinase activity is required for the prevention of neuronal apoptosis by IGF-1}

We examined next whether the activation of PI 3-kinase was necessary for the IGF-1-dependent promotion of survival. To do this, we used the fungal derivative wortmannin. Wortmannin has been shown previously to be a selective and potent inhibitor of PI 3-kinase in a number of experimental systems (Yano et al., 1993; Okada et al., 1994a,b; Ui et al., 1995). As shown in Figure 3, $A$ and $B$, when cultures were co-treated with IGF-1 and wortmannin (50 $\mathrm{nM}$ ), neuronal viability was $48.5 \pm 6.5 \%$ (6) of that observed with IGF-1 alone. The sharp reduction in viability with wortmannin is consistent with an involvement of PI 3-kinase in IGF-mediated inhibition of neuronal death (Fig. 3B). Recent reports from some laboratories have shown that at higher concentrations, wortmannin may also have inhibitory effects on other cellular targets. To verify our finding that PI 3-kinase was involved in IGF-1-mediated cell survival, we used another specific inhibitor of PI 3-kinase, LY 294002 (Sanchez-Margalet et al., 1994; Vlahos et al., 1994). As shown in Figure $3, A$ and $B$, and as observed with wortmannin, treatment of cultures maintained in IGF-1 with $10 \mu \mathrm{M} \mathrm{LY294002}$ caused extensive cell death $[42.5 \pm 4.7 \%$ (6) of cultures treated with IGF-1 alone].

A dose-response analysis of the effect of wortmannin revealed that a statistically significant effect on neuronal viability was detectable at doses $\geq 10 \mathrm{~nm}$ (Fig. $4 A$ ). The inhibitory effect of wortmannin on other enzymes occurs at micromolar concentrations (Okada et al., 1994a,b). The ability of wortmannin to inhibit neuronal survival at nanomolar doses, therefore, suggests that its effect is attributable to its established inhibitory action on PI 3-kinase. The concentration dependence of LY294002 on neuronal viability is shown in Figure $4 B$. Cell viability was significantly affected at concentrations of LY194002 $\geq 10 \mu \mathrm{M}$, a concentration similar to that determined previously to be required for its inhibition of PI 3-kinase (Sanchez-Margalet et al., 1994; Vlahos et al., 1994).

To demonstrate that wortmannin blocked PI 3-kinase activity, we performed in vitro assays of the enzyme immunoprecipitated from neurons using an anti-p85 antibody. PI 3-kinase activity was reduced in a concentration-dependent manner by wortmannin (Fig. 5). Under these conditions, the $\mathrm{IC}_{50}$ value was $\sim 3 \mathrm{~nm}$ wortmannin. When cells were treated in vivo with wortmannin (100 nM), the IGF-1-promoted PI 3-kinase activity was reduced by $61.7 \pm 4.9 \%$ (4). The concentrations of wortmannin that inhibited PI 3-kinase, therefore, were similar to those required to inhibit survival of neuronal cultures by IGF-1. Taken together, these results indicate that the survival of granule neurons by IGF-1 requires the activation of PI 3-kinase.

\section{Inhibition of PI 3-kinase is accompanied by DNA fragmentation, a hallmark of apoptosis}

We have shown previously that IGF-1 maintains granule neuron survival by blocking apoptosis (D'Mello et al., 1993). Blockade of IGF-1 signaling, therefore, would be expected to induce apoptosis. We proceeded to confirm that inhibition of PI 3-kinase, an essential component of IGF-1 signaling, induced death via apoptosis. A highly reliable biochemical marker of apoptotic death is the cleavage of genomic DNA into nonrandom, oligonucleosomal-size fragments. As shown in Figure 6, DNA isolated from neuronal cultures co-treated with IGF-1 and wortmannin displayed the characteristic "DNA ladder" of apoptosis. Significant fragmentation was observed at doses $\geq 10 \mathrm{nM}$, the same concentrations of wortmannin as those causing death. Not unexpectedly, virtually no DNA fragmentation was observed in IGF-1 treated cells in the absence of wortmannin. The similarity in the morphological appearance of cells dying as a result of lowering of $\mathrm{K}^{+}$in serum-free medium 

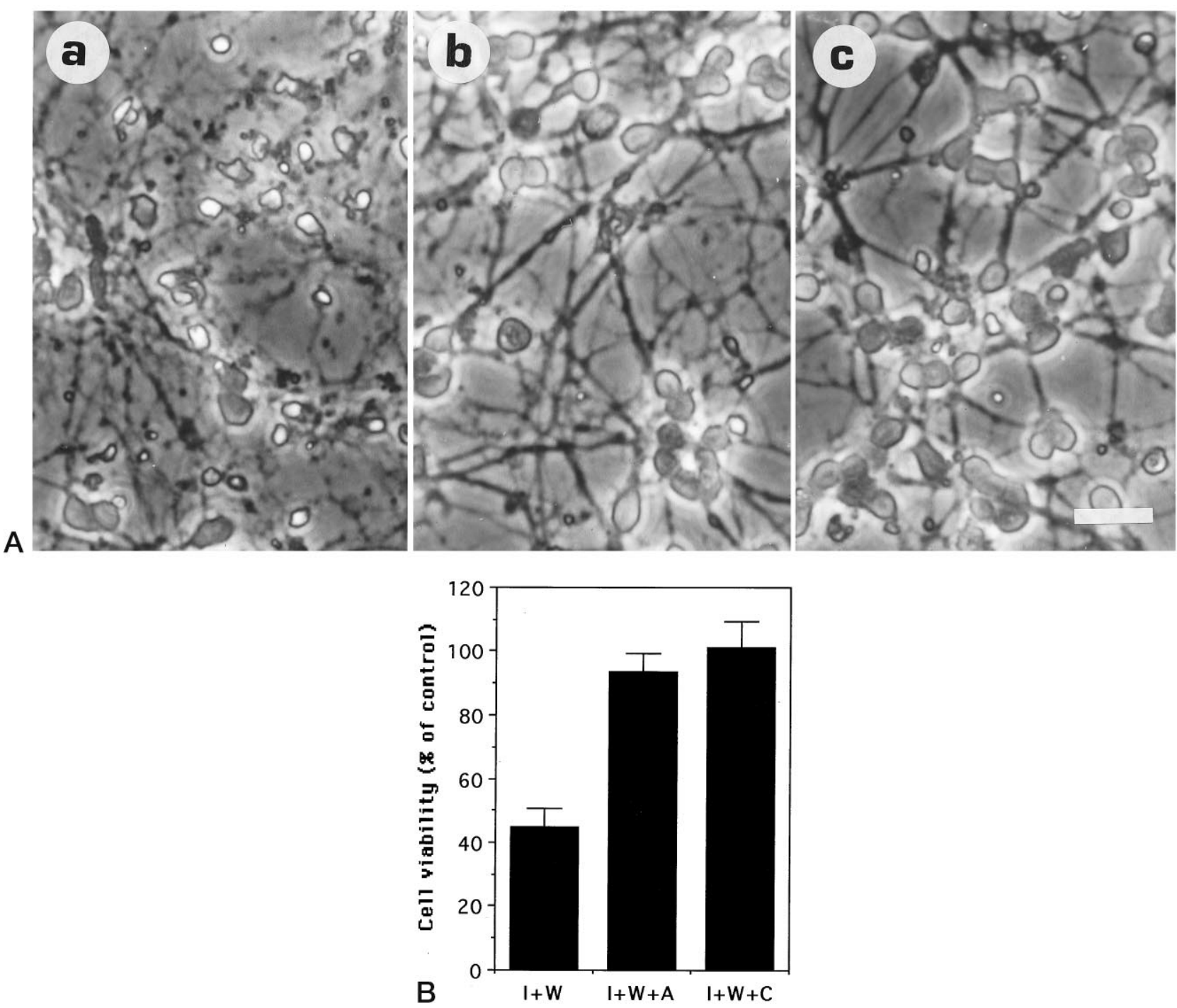

Figure 7. The transcriptional inhibitor actinomycin D and the translational inhibitor cycloheximide prevent wortmannin-promoted death. Neuronal cultures (7-d-old) were switched to serum-free medium containing $(a) 25 \mathrm{ng} / \mathrm{ml} \mathrm{IGF-1}+50 \mathrm{~nm}$ wortmannin $(I+W),(b) 25 \mathrm{ng} / \mathrm{ml} \mathrm{IGF}-1+50 \mathrm{nM}$ wortmannin $+2 \mu \mathrm{g} / \mathrm{ml}$ actinomycin D $(I+W+A)$, and $(c) 25 \mathrm{ng} / \mathrm{ml} \mathrm{IGF-1}+50 \mathrm{~nm}$ wortmannin $+10 \mu \mathrm{g} / \mathrm{ml}$ cycloheximide $(I+W+C)$. Data shown were obtained from two experiments performed in duplicate culture dishes. Two fields were examined from each dish. $A$, Morphological appearance at $24 \mathrm{hr}$ after treatment. Scale bar, $20 \mu \mathrm{m}$. B. Neuronal viability measured at the same time point as in $A$. The data are normalized to that obtained in the presence of $25 \mathrm{ng} / \mathrm{ml}$ IGF-1 without inhibitors.

to those exposed to wortmannin in IGF-1-containing medium suggests that wortmannin did not have a general necrotic effect on the cells.

\section{Wortmannin-mediated death of granule neurons can be prevented by inhibitors of gene expression}

In most cell culture paradigms, death by apoptosis can be delayed by inhibitors of RNA and protein synthesis. These findings have led to the hypothesis that apoptosis is dependent on the synthesis of new gene products and that trophic factors maintain survival by suppressing production of these potentially lethal molecules. We have shown previously that macromolecule synthesis inhibitors can prevent apoptosis of granule neurons caused by lowering of extracellular $\mathrm{K}^{+}$. To examine whether wortmannin-induced death could also be blocked by inhibitors of gene expression, we used the transcriptional inhibitor actinomycin $\mathrm{D}$ and the translational inhibitor cycloheximide. As shown in Figure 7, $A$ and $B$, both of these inhibitors of gene expression prevented wortmanninmediated neuronal death.

\section{Elevated $\mathrm{K}^{+}$mediated inhibition of apoptosis is not dependent on PI 3-kinase}

A number of polypeptide growth factors have been shown to be capable of activating PI 3-kinase in other cell types (Stephens et al., 1993; Kapeller and Cantley, 1994). Furthermore, activation of PI 3-kinase is known to be associated with a variety of biological effects such as membrane ruffling, chemotaxis, cell survival, and mitogenesis. To determine whether PI-3 kinase activation in granule neurons was in any way selective for the promotion of survival, we examined whether activation of receptor tyrosine kinases other than the IGF-1 receptor also activated PI 3-kinase. Neither bFGF nor BDNF activated PI 3-kinase (S. Soltoff and S. D'Mello, unpublished observations), although the receptors for both these growth factors are expressed in granule neurons (Bondy, 1991; 

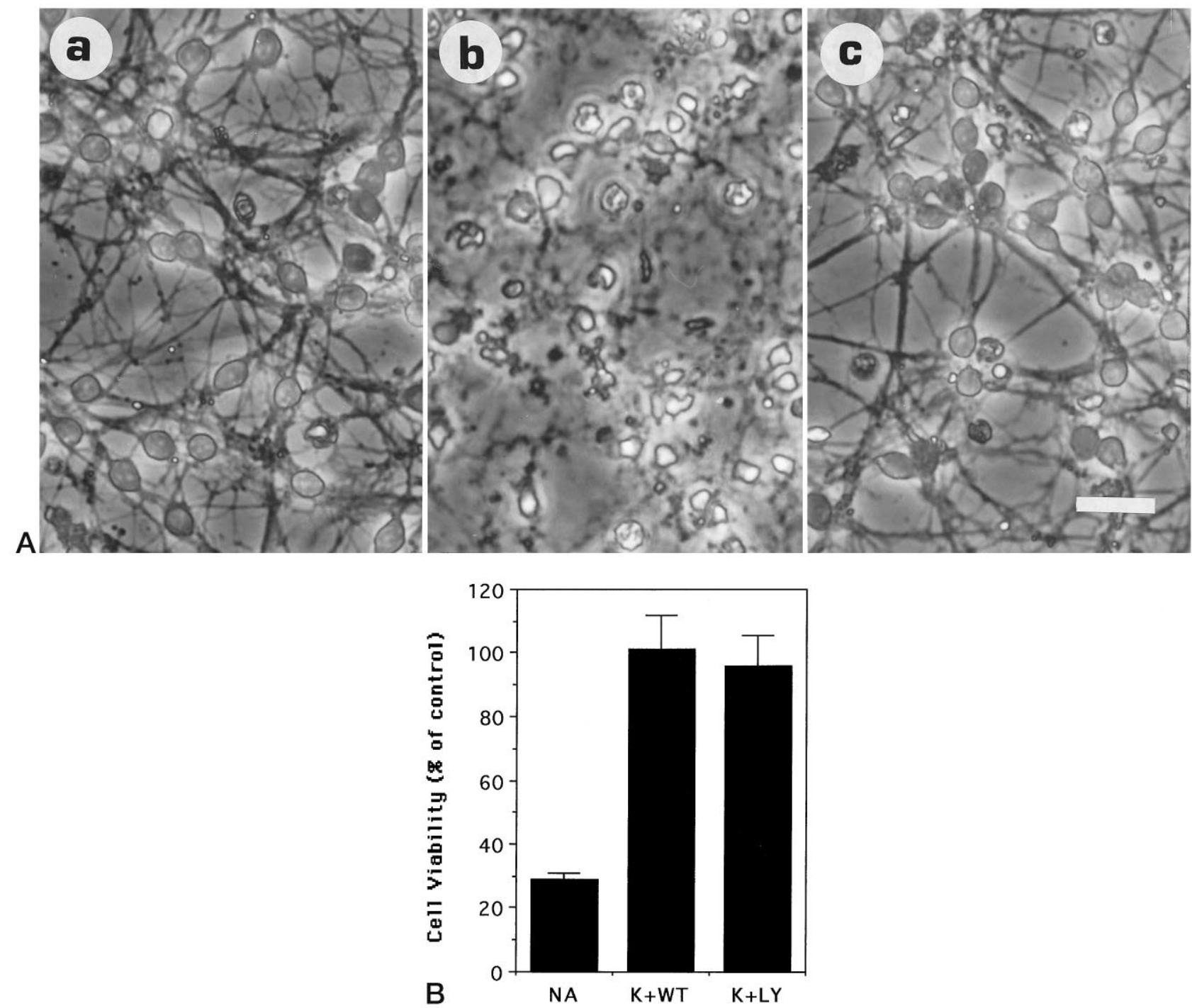

Figure 8. Wortmannin and LY249002 do not inhibit survival promoted by high $\mathrm{K}^{+}$. Granule neurons were switched to serum-free medium containing (a) $25 \mathrm{~mm} \mathrm{KCl},(b)$ no additives $\left(5 \mathrm{mM} \mathrm{K}^{+}\right)$, and $(c) 25 \mathrm{~mm} \mathrm{KCl}+50 \mathrm{~nm}$ wortmannin. $A$, Morphological appearance of neuronal cultures at 24 hr after treatment. Scale bar, $20 \mu \mathrm{m}$. B, Quantification of cell survival as measured by FDA staining. No additives, $25 \mathrm{~mm} \mathrm{KCl,} 50 \mathrm{~nm}$ wortmannin, and $10 \mu \mathrm{M}$ LY294002 are designated as $N A, K, W T$, and $L Y$, respectively. Error bars indicate mean \pm SD of data from three experiments performed in duplicate culture dishes. Two fields were examined from each dish. The data are normalized to that obtained in the presence of $25 \mathrm{~mm} \mathrm{KCl}$ without inhibitors. Similar results were observed in other experiments.

Klein et al., 1993; Ringstedt et al., 1993). As we have reported previously (D'Mello et al., 1993), neither bFGF nor BDNF has a significant survival effect on these neurons in our cell culture paradigm. This finding shows that polypeptide factors that do not promote survival fail to activate PI 3-kinase, suggesting that activation of this enzyme may be associated with the promotion of survival by growth factors such as IGF-1 and NGF (in PC12 cells).

The above observations raised the possibility that PI 3-kinase activation was critical and essential for survival of granule neurons. To address this issue, we examined whether PI 3-kinase was used by survival-promoting agents other than IGF-1. As described previously, one of the most efficient promoters of granule cell survival is an elevated level of extracellular $\mathrm{K}^{+}$(Lasher and Zaigon, 1972; Gallo et al., 1987; D’Mello et al., 1993, Yan et al., 1994). To examine whether PI 3-kinase activity was necessary for the survival-promoting action of elevated $\mathrm{K}^{+}$, granule cell cultures were switched to serum-free medium containing high $\mathrm{K}^{+}(25 \mathrm{~mm}$
$\mathrm{KCl})$ and wortmannin. In contrast to its lethal effect on cultures maintained in IGF-1, wortmannin had no effect on the ability of elevated $\mathrm{K}^{+}$to support survival. As shown in Figure 8, $A$ and $B$, viability of cultures shifted to serum-free medium containing high $\mathrm{K}^{+}$alone were comparable with those co-treated with high $\mathrm{K}^{+}$ and wortmannin. As observed with wortmannin, the survivalpromoting action of $\mathrm{K}^{+}$was also not affected by LY294002 (Fig. $8 B)$. We examined next whether DNA fragmentation occurred in neurons co-treated with elevated $\mathrm{K}^{+}$and wortmannin. As shown in Figure 9, no fragmentation of DNA was detectable in cells co-treated with $\mathrm{K}^{+}$and wortmannin, even when the drug was used at relatively high concentrations $(200 \mathrm{nM})$. This result suggests that wortmannin was not toxic to the cells but acted in a specific manner to induce apoptosis by blocking IGF-1-mediated activation of PI 3-kinase.

To confirm that the survival pathway of $\mathrm{K}^{+}$did not involve PI 3-kinase, we analyzed the activity of this enzyme after treatment 


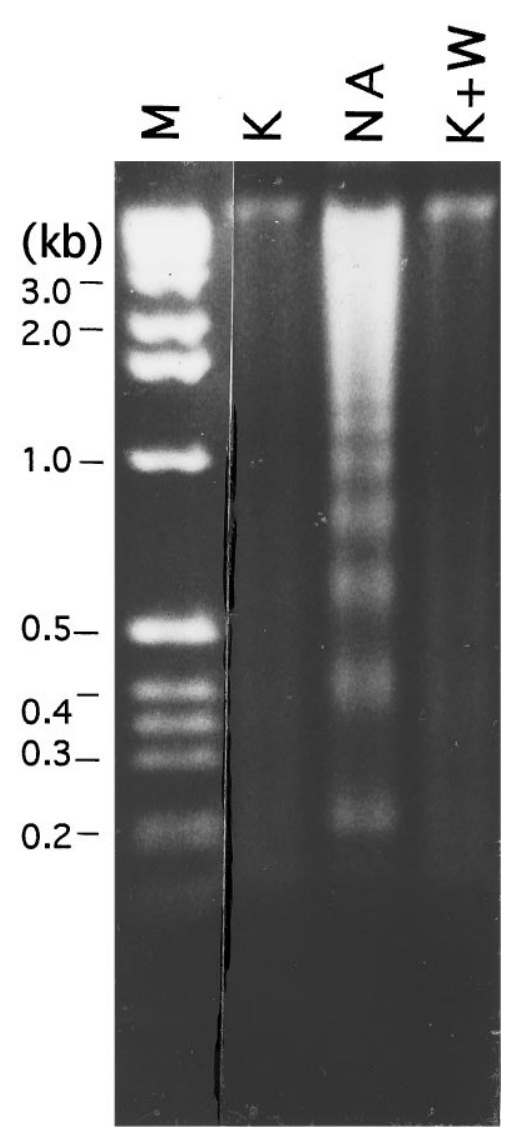

Figure 9. Fragmentation of DNA cannot be detected in cultures cotreated with wortmannin and $\mathrm{KCl}$. DNA fragmentation analysis of cultures maintained in high $\mathrm{KCl}(25 \mathrm{mM})$ and treated with $200 \mathrm{nM}$ wortmannin. Soluble DNA was isolated $18 \mathrm{hr}$ after the switch, as described in Materials and Methods, treated with RNase A, and subjected to electrophoresis. Lane $M$ contains a molecular weight marker, and numbers on the left represent lengths in kilobases $(k b)$. The figure shows DNA visualized by ethidium bromide staining.

of cells with high $\mathrm{K}^{+}$. In this experiment, neuronal cultures were switched to serum-free medium $\left(5 \mathrm{mM} \mathrm{K}^{+}\right)$containing no additives for $4 \mathrm{hr}$. High $\mathrm{K}^{+}$or IGF-1 was added to separate cultures, and PI 3-kinase activity was measured. As shown in Figure 10, the addition of IGF-1 caused a dramatic increase in PI 3-kinase activity. On the other hand, high $\mathrm{K}^{+}$had no significant effect on enzyme activity. Taken along with the lack of effect of wortmannin and LY294002 on various survival parameters, these results suggest that in contrast to the pathway activated by IGF-1, $\mathrm{K}^{+}$mediated survival does not require PI 3-kinase activity. Therefore, granule cell survival may be mediated by a PI 3-kinase-dependent as well as a PI 3-kinase-independent signaling pathway.

\section{DISCUSSION}

In this report, we describe two new findings. First, we present data consistent with a requirement for PI 3-kinase in the survivalpromoting action of IGF-1 in normal neurons. This finding supports the possibility that common signaling components are activated by NGF (in PC12 cells) and IGF-1 (in cerebellar granule neurons) toward the maintenance of cell survival. Secondly, we show that although necessary for IGF-1 signaling, PI 3-kinase activity is not required for the promotion of survival by elevated $\mathrm{K}^{+}$, implying that more than one pathway can mediate neuronal survival.

\section{Neuronal survival by IGF-1 is dependent on PI 3-kinase activity}

Regulation of neuronal survival is controlled by a complex array of intracellular signaling pathways. Most of these studies have been limited to the actions of NGF in PC12 cells. In additional to that of NGF, survival of a variety of neuronal types of can be maintained by IGF-1 (Aizenman and de Vellis, 1987; Caroni and Grandes, 1990, Svrzic and Schubert, 1990; D’Mello et al., 1993; Neff et al., 1993) (for review, see Bozyczko-Coyne et al., 1993). In contrast to the actions of NGF, however, little is known about how IGF-1 might exert its neurotrophic actions. Results from nonneuronal systems show that a major target of the IGF-1 receptor tyrosine kinase is IRS-1 (Lamphere and Lienhard, 1992; Myers et al., 1993; Hernandez-Sanchez et al., 1995) and, more recently, IRS-2. Exposure of cells to IGF-1 results in the tyrosine phosphorylation of IRS-1 and the subsequent recruitment of multiple SH2-containing signaling proteins, including PI 3-kinase, to specific binding motifs on IRS-1 (Myers et al., 1993; Kotani et al., 1994).

In this study, we investigated the role of PI 3-kinase in IGF-1 mediated survival of primary neurons. We report that PI 3-kinase may be a key component of the survival-promoting pathway activated by IGF-1 in granule neurons. Although definitive proof of the necessity for PI 3-kinase in neuronal survival may require experiments such as the overexpression of dominant-negative forms of the enzyme, we present compelling evidence that this is likely to be the case. IGF-1 produces a large increase in PI 3-kinase activity in granule cells, and a sustained activation continues up to $1 \mathrm{hr}$. Wortmannin, a highly selective inhibitor of PI 3-kinase ( $\mathrm{IC}_{50}, \sim 3 \mathrm{nM}$ in vitro $)$, blocks the in vivo activation of PI 3-kinase by IGF-1. Treatment with wortmannin also significantly blocks the survival-promoting action of IGF-1 and induces apoptosis at concentrations $\geq 10 \mathrm{~nm}$. It deserves mention that in some studies, wortmannin has been shown to inhibit other enzymes including myosin light-chain kinase, phosphatidylinositol 4-kinase, and phospholipase D. These effects, however, are observed at micromolar concentrations of this drug (Okada et al., 1994a,b). Additional support for the involvement of PI 3-kinase in neuronal survival comes from our finding that LY294002, another inhibitor of PI 3-kinase that is chemically unrelated to wortmannin, also blocks the survival action of IGF-1. Therefore, it is likely that IGF-1 maintains the survival of granule cells via a PI 3-kinasedependent pathway. The increase in PI 3-kinase activity of IGF1-treated cells was observed in both anti-P-Tyr immunoprecipitates and anti-IRS-1 immunoprecipitates. Thus, our data suggest that IGF-1 promotes the association of IRS-1 with PI 3-kinase in granule neurons.

\section{Inhibition of PI 3-kinase in neurons maintained in IGF-1 activates an apoptotic pathway}

DNA fragmentation, a characteristic feature of apoptotic death, is clearly detectable in wortmannin-treated neurons primed to die (Fig. 6). More important, fragmentation of DNA by wortmannin occurs at doses similar to that which causes cell death. An interesting feature of wortmannin-mediated cell death is that it can be prevented by transcriptional and translational inhibitors. The ability of transcriptional and translational inhibitors to prevent apoptosis is believed to be attributable to suppression of expression of specific genes (killer genes) that are required for the death process. Assuming that the effect of wortmannin on granule neurons maintained in IGF-1 is attributable to its inhibition of PI 3-kinase, it is possible that in healthy neurons, PI 3-kinase activation is 
Figure 10. IGF-1 but not $\mathrm{K}^{+}$increases PI 3-kinase activity in serum-deprived neurons. Cells were serum-starved and maintained overnight in medium containing 25 $\mathrm{mM} \mathrm{K} \mathrm{K}^{+}$and then switched for $4 \mathrm{hr}$ to a serum-free medium containing $5 \mathrm{~mm} \mathrm{~K}^{+}$. Cells were then exposed acutely to $25 \mathrm{~mm}$ $\mathrm{K}^{+}$for 1 or $5 \mathrm{~min}\left(K 1^{\prime}\right.$ or $\left.K 5^{\prime}\right)$ or IGF-1 (25 ng/ml) for $1 \mathrm{~min}$. PI 3-kinase was immunoprecipitated from the cleared lysates using anti-P-Tyr antibody $(6.6 \mu \mathrm{g} / \mathrm{ml})$. Left panel, PI 3-kinase activity was measured in a lipid kinase assay using PI-4,5-P2 as a substrate. PI-3,4,5-P3 (PIP3), the main product of the lipid kinase assay, was separated using thin-layer chromatography. Right panel, The immunoprecipitated proteins used in the lipid kinase assay were subjected to SDS-PAGE, transferred to nitrocellulose filters, and probed overnight with anti-p85 antibody (1:8000 dilution). The arrow on the right indicates the location of $\mathrm{p} 85$. IGF-1, but not $\mathrm{K}^{+}$, produced an increase in the association of $\mathrm{p} 85$ with the anti-P-Tyr antibody. Similar results to those shown in top and bottom panels were obtained in at least two other additional experiments. See Materials and Methods for additional details.
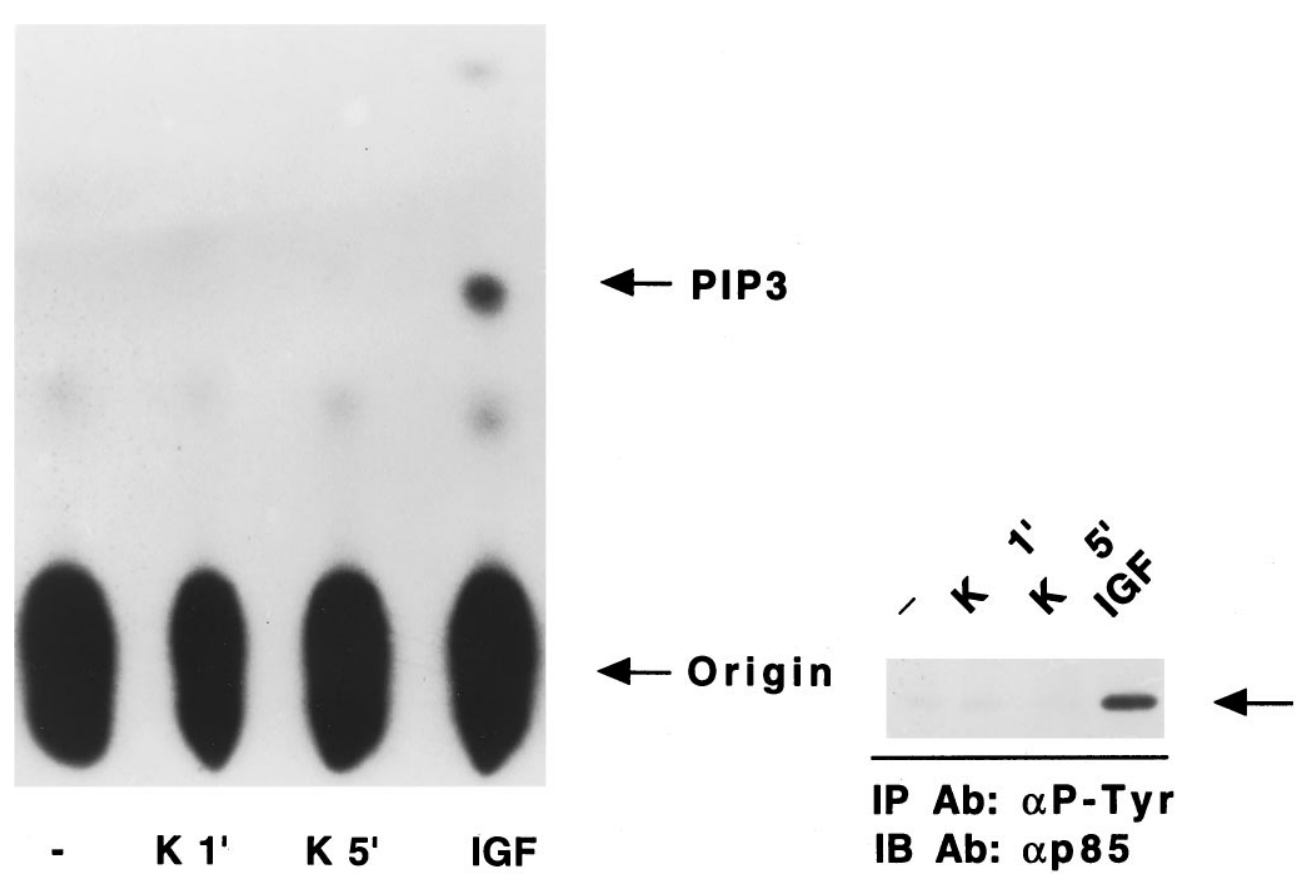

upstream of the suppression of killer genes. Blockade of PI 3-kinase activity, therefore, may relieve this suppression, resulting in the expression of killer genes that ultimately causes cell death.

Interestingly, both the IGF-1 receptor and the PI 3-kinase mRNAs are expressed in the cerebellar granule cell layer of the rodent brain (Bondy, 1991; Folli et al., 1994; Ito et al., 1995), suggesting that the trophic actions of IGF-1 in vivo may also be mediated through PI 3-kinase activation. It is likely that this activation of PI-3 occurs via IRS-1. Intriguingly, in a recent study by Folli et al. (1994), IRS-1 immunoreactivity was not detectable in the internal granule layer of the rat cerebellum. Expression of IRS-1 in granule neurons in vivo may be low and possibly below the detection level of immunocytochemical techniques. Alternatively, IGF-1 signaling might occur via IRS-2, for which a detailed localization study has not been reported. In this regard, the anti-IRS-1 antibody used in this study was generated to a peptide sequence to IRS-1 before the initial report of IRS-2, and the antibody has not been examined for its ability to recognize IRS-2.

The necessity for PI 3-kinase in survival promotion by both NGF and IGF-1 raises the possibility that although acting on distinct tyrosine kinase receptors, the two factors might activate common intracellular signaling pathways. Other polypeptide factors acting through tyrosine kinase receptors may also use the same signaling components (such as PI 3-kinase) to maintain survival. Support for this idea comes from the finding that PDGF-mediated survival of PC12 cells may also involve PI 3-kinase. Apoptosis of PC12 cells could be prevented by platelet-derived growth factor (PDGF) in cell lines engineered to express the wild-type PDGF receptor, but not in cells expressing a mutated PDGF receptor unable to bind PI 3-kinase (Yao and Cooper, 1995).

\section{PI 3-kinase is not required for survival promoted by elevated $K^{+}$}

We examined whether PI 3-kinase was a central and essential component of the biochemical machinery used by granule neurons for survival. These experiments were prompted by our ob- servation that factors (bFGF and BDNF) that did not affect survival of granule cells in this paradigm also did not activate PI 3-kinase. Interestingly, neither wortmannin nor LY294002 affected the ability of high $\mathrm{K}^{+}$to maintain survival, even when used at high doses. DNA fragmentation was also not detected in neurons maintained in elevated $\mathrm{K}^{+}$and treated with wortmannin. In addition, PI 3-kinase was not activated when cells were shifted from serum-free medium containing the normal $\mathrm{K}^{+}$concentration $(5 \mathrm{mM})$ to that which contained the high concentration $(25 \mathrm{~mm})$. It appears, therefore, that high $\mathrm{K}^{+}$maintains neuronal survival by a PI 3-kinase-independent pathway that is distinct from that activated by IGF-1. It is generally believed that cell survival is regulated by a common biochemical pathway. If this is in fact the case, our results suggest that PI 3-kinase activation in the IGF-1 pathway lies upstream of the point at which the high- $\mathrm{K}^{+}$and IGF-1 pathways converge.

Results from a previous study by Galli et al. (1995) have also provided evidence that IGF-1 and high $\mathrm{K}^{+}$act through distinct mechanisms in cerebellar granule neurons. These authors showed that although influx of $\mathrm{Ca}^{+}$through voltage-gated channels is involved in the survival-promoting pathway of elevated $\mathrm{K}^{+}$, it does not occur with IGF-1. Like IGF-1, the cyclic AMP elevating agent forskolin, which is also capable of maintaining survival of granule neurons in culture (D'Mello et al., 1993), did not stimulate $\mathrm{Ca}^{+}$ influx (Galli et al., 1995). Although this result raises the possibility that IGF-1 and forskolin may act by a common mechanism that is not associated with $\mathrm{Ca}_{2}{ }^{+}$influx, we have observed recently that forskolin-mediated survival is not inhibited by wortmannin (K. Borodezt and S. D'Mello, unpublished observations). Hence, based on influx of $\mathrm{Ca}^{+}$and PI 3-kinase-dependence, it is likely that $\mathrm{K}^{+}$, IGF-1, and cAMP act by three distinct mechanisms.

In addition to PI 3-kinase, mitogen-activated protein kinase family members have been shown to both positively and negatively regulate cell death. Xia et al. (1995) showed recently that in NGF-differentiated PC12 cells, which undergo apoptosis at NGF deprivation, the extracellular signal-regulated kinase was involved 
in maintaining survival, whereas activation of c-jun NH2-terminal protein kinase (JNK) induced apoptosis. Earlier studies have shown that the expression of c-jun, a target of JNK, is induced in cultured sympathetic neurons during apoptosis and is involved in the mediation of cell death (Estus et al., 1994; Ham et al., 1995). It remains to be tested whether extracellular signal-regulated kinase and JNK are involved in the survival-promoting action of IGF-1 in granule neurons. Another molecule that might be involved in PI-3 kinase-mediated survival is the Akt kinase. Akt has been shown previously to be a target of PDGF-activated PI 3-kinase (Burgering and Coffer, 1995; Franke et al., 1995).

Massive degeneration of cerebellar Purkinje neurons as well as granule cells occurs in ataxia telangiectasia (AT), a human genetic disorder afflicting children. Recently, the gene encoding the mutated protein in AT was identified and found to structurally resemble the PI 3-kinase gene (Lavin et al., 1995; Savitsky et al., 1995). It is not yet known whether the normal AT gene does, in fact, encode an enzyme with PI 3-kinase activity or whether patients with AT have a deficiency in PI-3 kinase activity. Assuming this to be the case, however, it is tempting to speculate that finding out how elevated $\mathrm{K}^{+}$promotes survival independently of PI 3-kinase could lead to the development of therapeutic approaches toward preventing the neuronal loss that occurs in AT.

\section{REFERENCES}

Aizenman Y, de Vellis J (1987) Brain neurons develop in a serum and glial free environment: effects of transferrin, insulin, insulin-like growth factor I, and thyroid hormone on neuronal survival, growth, and differentiation. Brain Res 406:32-42.

Batistatou A, Greene LA (1991) Aurintricarboxylic acid rescues PC12 cells and sympathetic neurons from cell death caused by nerve growth factor deprivation: correlation with suppression of endonuclease activity. J Cell Biol 115:461-471.

Beck KD, Powell-Braxton L, Widmer H-R, Valverde J, Hefti F (1995) IGF1 gene disruption results in reduced brain size, CNS hypomyelination, and loss of hippocampal granule and striatal parvalbumincontaining neurons. Neuron 14:717-730.

Bondy CA (1991) Transient IGF-1 gene expression during the maturation of functionally related central projection neurons. J Neurosci 11:3442-3455.

Bozyczko-Coyne D, Glicksman MA, Prantner JE, McKenna B, Connors T, Friedman C, Dasgupta M, Neff NT (1993) IGF-1 supports the survival and/or differentiation of multiple types of central nervous system neurons. Ann NY Acad Sci 692:311-313.

Burgering BMT, Coffer PJ (1995) Protein kinase B (c-Akt) in phosphatidylinositol-3-OH kinase signal transduction. Nature 376:599-602.

Calissano P, Ciotti MT, Battistini L, Zona C, Angelini A, Merlow D, Mercanti D (1993) Recombinant human IGF-1 exerts a trophic action and confers glutamate-sensitivity to glutamate-resistant granule cells. Proc Natl Acad Sci USA 90:8752-8756.

Cantley LC, Auger KR, Carpenter C, Duckworth B, Graziani A, Kapeller R, Soltoff S (1991) Oncogenes and signal transduction. Cell 64:281-302.

Caroni P, Grandes P (1990) Nerve sprouting in innervated adult skeletal muscle induced by exposure to elevated levels of insulin-like growth factors. J Cell Biol 110:1307-1317.

Carpenter CL, Duckworth BC, Auger KR, Cohen B, Schaffhausen BS, Cantley LC (1990) Purification and characterization of phosphoinositide 3-kinase from rat liver. J Biol Chem 265:19704-19711.

Chao M (1992) Neurotrophin receptors: a window into neuronal differentiation. Neuron 9:583-593.

Cordon-Cardo C, Tapley P, Jing SQ, Nanduri V, O’Rourke E, Lamballe F, Kovary K, Klein R, Jones KR, Reichardt LF, Barbacid M (1991) The trk tyrosine protein kinase mediates the mitogenic properties of nerve growth factor and neurotrophin-3. Cell 66:173-183.

Cull-Candy SG, Howe JR, Ogden DC (1988) Noise and single channels activated by excitatory amino acids in rat cerebellar granule neurons. J Physiol (Lond) 400:189-222.

D’Mello SR, Galli C, Ciotti T, Calissano P (1993) Induction of apoptosis in cerebellar granule neurons by lowering of extracellular potassium: inhibition of death by IGF-1 and cAMP. Proc Natl Acad Sci USA 90:10989-10993.

Escobedo J, Navankasattusas S, Kavanaugh WM, Milfay D, Fried VA, Williams LT (1991) cDNA cloning of a novel $85 \mathrm{kd}$ protein that has $\mathrm{SH} 2$ binding domains and regulates binding of PI 3-kinase to the PDGF beta receptor. Cell 65:75-82.

Estus S, Zaks WJ, Freeman RS, Gruda M, Bravo R, Johnson EM (1994) Altered gene expression in neurons during programmed cell death: identification of c-jun as necessary for neuronal apoptosis. J Cell Biol 127:1717-1727.

Folli F, Bonfanti L, Renard E, Kahn CR, Merighi A (1994) Insulin receptor substrate-I (IRS-I) distribution in the rat central nervous system. J Neurosci 14:6412-6422.

Franke T, Yan S, Chan T, Datta K, Kazlauskas A, Morrison DK, Kaplan DR, Tsichlis PN (1995) The protein kinase encoded by the Akt protooncogene is a target of the PDGF-activated phosphatidylinositol 3-kinase. Cell 81:727-36.

Galli C, Meucci O, Scorziello A, Werge TM, Calissano P, Schettini G (1995) Apoptosis in cerebellar granule neurons is blocked by high $\mathrm{KCl}$, forskolin, and IGF-I through distinct mechanisms of action: the involvement of intracellular calcium and RNA synthesis. J Neurosci 15:1172-1179.

Gallo V, Kingsbury A, Balazs R, Jorgensen OS (1987) The role of depolarization in the survival and differentiation of cerebellar granule cells in culture. J Neurosci 7:2203-2213.

Gao W-Q, Heintz N, Hatten ME (1991) Cerebellar granule cell neurogenesis is regulated by cell-cell interactions in vitro. Neuron 6:705-715.

Greene LA, Tischler AS (1976) Establishment of a noradrenergic clonal line of rat adrenal pheochromocytoma cells which respond to nerve growth factor. Proc Natl Acad Sci USA 73:2424-2428.

Ham J, Babij C, Whitfield J, Pfarr CM, Lallemand D, Yaniv M, Rubin LL (1995) A c-jun dominant negative mutant protects sympathetic neurons against programmed cell death. Neuron 14:927-939.

Harrison SC (1996) Peptide-surface association: the case of PDZ and PTB domains. Cell 86:341-343.

Hernandez-Sanchez C, Blakesley V, Kalebic T, Helman L, LeRoith D (1995) The role of the tyrosine kinase domain of the insulin-like growth factor-I receptor in intracellular signaling, cellular proliferation, and tumorigenesis. J Biol Chem 270:29176-29181.

Hiles I, Otsu M, Volinia S, Fry MJ, Gout I, Dhand R, Panayotou G, Ruiz-Larrea F, Thompson A, Totty NF, Hsuan JJ, Courtneidge SA, Parker PJ, Waterfield MD (1992) Phosphatidylinositol 3-kinase: structure and expression of the $110 \mathrm{kd}$ catalytic subunit. Cell 70:419-429.

Hockberger PE, Tseng HY, Connor JA (1987) Immunocytochemical and electrophysiological differentiation or rat cerebellar granule cells in explant cultures. J Neurosci 7:1370-1383.

Ito Y, Goto K, Kondo H (1995) Localization of mRNA for phosphatidylinositol 3-kinase in brain of developing and mature rats. Mol Brain Res 34:149-153.

Johnson EM, Deckworth TL (1993) Molecular mechanisms of developmental neuronal death. Annu Rev Neurosci 16:31-46.

Jones KH, Senft JA (1985) An improved method to determine cell viability by simultaneous staining with fluorescein diacetate and propidium iodide. J Histochem Cytochem 33:77-79.

Kapeller R, Cantley LC (1994) Phosphatidylinositol 3-kinase. BioEssays 16:565-576.

Klein R, Martin-Zanca Barbacid M, Parada LF (1993) Expression of the tyrosine kinase receptor trkB is confined to the murine embryonic and adult nervous system. Development 109:845-850.

Kotani K, Yonezawa K, Hara K, Ueda H, Kitamura Y, Sakaue H, Ando A, Chavvanieu A, Calas B, Grigorescu F, Nishiyama M, Waterfield MD, Kasuga M (1994) EMBO J 13:2313-2321.

Lamphere L, Lienhard GE (1992) Components of signaling pathways for insulin and insulin-like growth factor-I in muscle myoblast and myotubes. Endocrinology 131:2196-2202.

Lasher RS, Zaigon IS (1972) The effect of potassium on neuronal differentiation in cultures of dissociated new born rat cerebellum. Brain Res 41:428-488.

Lavin MF, Khanna KK, Beamish H, Spring K, Watters D, Shiloh Y (1995) Relationship of the ataxiua-telangiectasia protein ATM to phosphoinositide 3-kinase. Trends Biochem Sci 20:382-383.

Levi G, Aloisi F, Ciotti MT, Gallo V (1984) Autoradiographic localization and depolarization-induced release of acidic amino acids in differentiating cerebellar granule cell cultures. Brain Res 290:77-86. 
Marshall CJ (1995) Specificity of receptor tyrosine kinase signaling: transient versus sustained extracellular signal-regulated kinase activation. Cell 80:179-185.

Mesner PW, Winters TR, Green SH (1992) Nerve growth factor withdrawal-induced cell death in neuronal PC12 cells resembles that in sympathetic neurons. J Cell Biol 119:1669-1680.

Morgan SJ, Smith AD, Parker PJ (1990) Purification and characterization of bovine brain type 1 phosphatidylinositol 3 kinase. Eur J Biochem 191:761-767.

Myers MG, Sun XJ, Cheatham B, Jachna BR, Glasheen EM, Backer JM, White MF (1993) IRS-I is a common element in insulin and insulinlike growth factor-I signaling to the phosphatidylinositol 3 'kinase. Endocrinology 132:1421-1430.

Neff NT, Prevette D, Houenou LJ, Lewis ME, Glicksman MA, Yin QW, Oppenheim RW (1993) Insulin-like growth factors: putative musclederived trophic agents that promote motoneuron survival. J Neurobiol 24:1578-1588. ,

Obermeier A, Bradshaw RA, Seedorf K, Choidas A, Schlessinger J, Ullrich A (1994) Neuronal differentiation signals are controlled by nerve growth factor receptor/trk binding sites for SHC and PLC gamma. EMBO J 13:1585-1590.

Okada T, Sakuma L, Fukui Y, Hazeki O, Ui M (1994a) Blockage of chemotactic peptide-induced stimulation of neutrophils by wortmannin as a result of selective inhibition of phosphatidylinositol 3-kinase. J Biol Chem 269:3563-3567.

Okada T, Kawano Y, Sakakibara T, Hazeki O, Ui M (1994b) Essential role of phosphatidylinositol 3-kinase in insulin-induced glucose transport and antipolysis in rat adipocytes. J Biol Chem 269:3568-3573.

Oppenheim RW (1991) Cell death during development of the nervous system. Annu Rev Neurosci 14:453-501.

Qui M, Green S (1992) PC12 neuronal differentiation is associated with prolonged p21 ras activity and consequent prolonged ERK activity. Neuron 9:705-717.

Ringstedt T, Lagercrantz H, Persson H (1993) Expression of the trk family in the developing postnatal rat brain. Dev Brain Res 72:119-131.

Rukenstein A, Rydel R, Greene L (1991) Multiple agents rescue PC12 cells from serum-free cell death by translation-and transcription independent mechanisms. J Neurosci 11:2552-2563.

Sanchez-Margalet V, Goldfine ID, Vlahos CJ, Sung CK (1994) Role of ophosphatidylinositol-3-kinase in insulin receptor signaling: studies with inhibitor, LY294002. Biochem Biophys Res Commun 204:446-452.

Savitsky K, Bar-Shira Gilad S, Rotman G, Ziv Y, Vanagaite L, Tagle DA, Smith S, Uziel T, Sfez S, Ashkenazi M, Pecker I, Frydman M, Harnik R, Patanjali SR, Simmons A, Clines GA, Sartiel A, Gatti RA, Chessa L, Sanal O, Lavin MF, Jaspers NGJ, Taylor MR, Arlett CF, Miki T, Weissman SM, Lovett M, Collins FS, Shiloh Y (1995) A single ataxia telangiectasia gene with a product similar to PI-3 kinase. Science 268:1749-1753.

Schlessinger J, Ullrich A (1992) Growth factor signaling by receptor tyrosine kinases. Neuron 9:383-391.

Schlessinger J, Mohammadi M, Margolis B, Ullrich A (1992) Role of SH2-containing proteins in cellular signaling by receptor tyrosine kinases. Cold Spring Harb Symp Quant Biol 57:67-74.

Soltoff SP, Carraway KL, Prigent SA, Gullick WG, Cantley LC (1994)
ErbB3 is involved in activation of phosphatidylinositol 3-kinase by epidermal growth factor. Mol Cell Biol 14:3550-3558.

Stephens LR, Jackson TR, Hawkins PT (1993) Agonist-stimulated synthesis of phosphatidylinositol $(3,4,5)$-trisphosphate: a new intracellular signalling system. Biochim Biophys Acta 1179:27-75.

Sun XJ, Rothenberg P, Kahn CR, Backer JM, Araki E, Wilden P, Cahill DA, Goldstein BJ, White MF (1991) Structure of the insulin receptor substrate IRS-I defines a unique signal transduction protein. Nature 352:73-77.

Sun XJ, Miralpeix M, Myers Jr MG, Glasheen EM, Backer JM, Kahn CR, White MF (1992) Expression and function of IRS-I in insulin signal transmission. J Biol Chem 267:22662-22672.

Svrzic D, Schubert D (1990) Insulin-like growth factor I supports embryonic nerve cell survival. Biochem Biophys Res Commun 172:54-60.

Thangnipon W, Kingsbury A, Webb M, Balazs R (1983) Observations on rat cerebellar granule cells in vitro: influence of substratum, potassium concentration and relationship between neurons and astrocytes. Dev Brain Res 11:177-189.

Toker A, Meyer M, Reddy KK, Falck JR, Aneja R, Aneja S, et al (1994) Activation of protein kinase $\mathrm{C}$ family members by the novel polyphosphoinositides PtdIns-3,4-P2 and PtdIns-3,4,5-P3. J Biol Chem 269:32358-32367.

Traverse S, Seedorf K, Paterson H, Marshall CJ, Cohen P (1992) Sustained activation of the mitogen-activated protein (MAP) kinase cascade may be required for differentiation of PC12 cells. Comparison of the effects of nerve growth factor and epidermal growth factor. Biochem J 288:351-355.

Ui M, Okada T, Hazeki K, Hazeki O (1995) Wortmannin as a unique probe for an intracellular signalling protein, phosphoinositide 3-kinase. Trends Pharmacol 20:303-307.

Valius M, Kazlauskas A (1993) Phospholiase C-gamma 1 and phosphatidylinositol 3 kinase are the downstream mediators of the PDGF receptor's mitogenic signal. Cell 73:321-334.

Vlahos CJ, Matter WF, Hui KY, Brown RF (1994) A specific inhibitor of phosphatidylinositol 3-kinase, 2-(4-morpholinyl)-8-phenyl-4H-1benzopyran-4-one (LY294002). J Biol Chem 269:5241-5248.

Xia Z, Dickens M, Raingeaud J, Davis RJ, Greenberg ME (1995) Opposing effects of ERK and JNK-p38 MAP kinases on apoptosis. Science 270:1326-1331.

Yan G-M, Binhui N, Weller M, Wood KA, Paul SM (1994) Depolarization or glutamate receptor activation blocks apoptotic cell death of cultured cerebellar granule neurons. Brain Res 656:43-51.

Yano H, Nakanishi S, Kimura K, Hanai N, Saitoh Y, Fukui Y, Nonomura Y, Matsuda Y (1993) Inhibition of histamine secretion by wortmannin through the blockade of phosphatidyl 3-kinase in RBL-2H3 cells. J Biol Chem 268:25846-25856.

Yao R, Cooper GM (1995) Requirement for phosphatidylinositol-3 kinase in the prevention of apoptosis by nerve growth factor. Science 267:2003-2006.

Ye P, Xing Y, Dai Z, D'Ercole AJ (1996) In vivo actions of insulin-like growth factor-I (IGF-I) on cerebellum development in transgenic mice: evidence that IGF-I increases proliferation of granule cell progenitors. Dev Brain Res 95:44-54. 